\title{
The Specific Application and Practice of Cognitive Behavioral Religious Therapy in Junior High School Students' Mental Health Group Counseling Education: A Case Study from East Java
}

\author{
Chemealy Alisha \\ Faculty of Psychology, University of Muhammadiyah Malang
}

\begin{abstract}
This study aims to determine the effectiveness of Detox Mind through Cognitive Behavior Religious Therapy training in reducing depression levels and increasing Psychological Well-Being levels in students who are active in organizations in East Java. The detox mind program through Cognitive Behaviour Religious Therapy training consists of five sessions with four meetings with 60-120 minutes. This study is an experimental study using a pretest-posttest design. Eleven students who were active in organizations in East Java participated in the study; they joined in more than two organizations, were between semester 1 and semester 2, and were males and females. The scales used in the study were the Beck Depression Inventory-II (BDI-II) scale and the Psychological Well-Being scale with data analysis using the Wilcoxon Signed Rank Test to measure differences in pretest and final test. The result of the current study indicates that, on the depression scale, there is a significant difference between the results of the pretest and posttest with a value of $p=$ $0.075<0.05$, negative ranks with a value of $N=4$, mean ranks 3.25, the sum of ranks $=13.00$, and positive ranks with a value of $N=7$, an average rating of 7.57, and the sum of ranks of 53.00. Meanwhile, the results of the psychological well-being scale test showed that there was a difference between the results of the pretest and posttest with a p-value of $0.007<0.05$, with negative ranks $N=1$, mean ranks $=2.50$, the sum of ranks=2.50, and with positive ranks of $N=10$, mean ranks=6.35, and the sum of ranks=63.50.
\end{abstract}

Keywords: detox mind, Islamic-based learning, psychological well-being, active students in organizations, East Java

\section{Introduction}

In December 2019, a new virus called Covid 19 appeared for the first time in Wuhan, China. It attracted the world's attention and became the world's biggest social problem. According to WHO, Covid-19 had exposed more than 183 countries around the world, including Indonesia (Mansuri, 2020). The increasing number of transmissions of this virus had made the government issue various policies to carry out Large-Scale Social Restrictions (PSBB) in early 2020, and again provided a new policy, namely the Enforcement of Restrictions on Community Activities (PPKM) in July 2021. These policies included social and physical distancing, limiting social interaction with other people, reducing activities outside the home, and carrying out activities indoors because the virus was transmitted through direct contact. The policies due to this epidemic have significant impacts and can hamper various life practices such as economic, social, cultural, and especially in the education sector.

The impact of the Covid-19 outbreak on education requires academics to think about the learning methods and models that are relevant to use during the Covid-19 pandemic. As a result, the Ministry of Education issued a policy to stop faceto-face learning activities become online learning. Online learning is considered the best and most appropriate option because of its flexibility, allowing students to access information and learning resources without being limited by space and time. However, as time goes by, online learning also brings several negative impacts on students, including mental health, impaired physical fitness, and poor psychological well-being, especially the students who are active in organizations.

Most university students are in the range of 18-24 years, in which, according to the stages of development, they are at the early adult development stage (Santrock, 2012). At this development period, many individuals are exploring careers they want to pursue, the type of individual they want to be, and the kind of lifestyle they want to have. For new students in semesters 1 and 2, the transition from high school to college involves a stronger mentality. New students must be able to interact with new friends from a broader background and more diverse ethnicity. Santrock (2012) states that students have more mature feelings, have greater opportunities to explore diverse values and lifestyles, and are more intellectually challenged by academic loads and tasks (Santrock \& Halonen, 2010).

The academics' policies that replace all learning activities into online mode continue to limit activities outside the home and have to do everything at home not only affect someone's daily life, disrupting physical fitness but can also cause many psychosocial problems. One of the effects of online learning is the increased use of electronic devices such as laptops and cellphones, resulting in changes in hemostasis from sleep. According to Voitsidis research, sleep disorders such as insomnia are affecting many people during this Covid-19 pandemic. It results in increased stress 
levels and concerns about health, finances, welfare, and changes in social life. An article describing a survey related to students' mental health during the pandemic reveals that $91 \%$ of students experienced stress or anxiety, $81 \%$ felt disappointed or sad, $80 \%$ felt lonely or isolated, $48 \%$ experienced financial problems, and $56 \%$ experienced relocation (Zalaznick, 2020). In addition, the academic loads and other campus activities as one of the responsibilities as a "student" must still be fulfilled. In dealing with these developmental tasks, it is not uncommon to find problems that trigger stress. The effects of these stresses range from minor things, such as headaches and lack of appetite, to the fatal thing, which is suicide.

\section{Hypothesis}

- The Islamic-based detox mind based on the Cognitive Behaviour Religious Therapy technique can reduce the level of depression in students who are active in organizations.

- The Islamic-based detox mind based on Cognitive Behaviour Religious Therapy techniques can increase the level of Psychological Well-Being in students who are active in organizations.

\section{Methods}

The current study has two variables, namely detox mind as the independent variable (X) and depression and psychological well-being as the dependent variable (Y). Participants taking part in the detox program in the study are 11 students who are active in organizations and selected based on the following criteria; (1) active in organizations; (2) males and females; (3) participating in more than two organizations; (4) in the semester 1-2; (5) having a moderate-high level of depression after being measured by the Beck Depression Inventory-II (BDI-II) scale (Beck 1996); (6) having a psychological well-being level with a categoryoflow after being measured by the Psychological Well-Being scale (Ryff et al., 2011); and (7) willing to follow or participate in the detox mind program. The instruments used in this study are informed consent, the detox mind program module, assignments, depression scale, psychological well-being scale, and interviews.

The research method of the currents study was preexperimental with the One Group Pretest-Posttest Design model. Measurements were taken before the intervention (pretest) and after the intervention (posttest). The intervention provided was in the form of a mind detox program carried out six times through online meetings with a duration of 60-120 minutes. The data of this study were then analyzed using Wilcoxon signed-rank difference test to determine the difference before and after treatments.

\section{Results}

Table 1 shows the results of the participants' pretest and posttest on the depression scale and psychological wellbeing scale.
Table 1: Depressionpsychological well-being

\begin{tabular}{|c|c|c|c|}
\hline \multicolumn{2}{|c|}{ Depression } & \multicolumn{2}{c|}{ psychological well-being } \\
\hline Pretest & Posttest & Pretest & Posttest \\
\hline 61 & 57 & 157 & 167 \\
\hline 58 & 53 & 149 & 189 \\
\hline 43 & 49 & 148 & 168 \\
\hline 56 & 53 & 131 & 143 \\
\hline 43 & 61 & 140 & 153 \\
\hline 47 & 55 & 166 & 182 \\
\hline 56 & 65 & 153 & 166 \\
\hline 52 & 72 & 183 & 214 \\
\hline 36 & 48 & 152 & 156 \\
\hline 59 & 49 & 184 & 190 \\
\hline 46 & 57 & 163 & 157 \\
\hline
\end{tabular}

The results of hypothesis testing are based on nonparametric statistical methods of Wilcoxon Signed Ranks analysis. This analysis was used to determine the difference between the pretest score and the posttest score. In summary, the Wilcoxon Signed Ranks test results are presented in Table 1.3 .

Table 2: Depression Ranks

\begin{tabular}{|c|c|c|c|c|}
\hline & & $\mathrm{N}$ & Mean Ranks & Sum of Ranks \\
\hline \multirow{4}{*}{$\begin{array}{l}\text { Post Test - } \\
\text { Pre Test }\end{array}$} & Negative Ranks & $4^{\mathrm{a}}$ & 3.25 & 13.00 \\
\hline & Positive Ranks & $7^{\mathrm{b}}$ & & \\
\hline & Ties & $0^{\circ}$ & 7.57 & 53.00 \\
\hline & Total & 11 & & \\
\hline
\end{tabular}

a. Posttest < Pretest

b. Posttest $>$ Pretest

c. Posttest $=$ Pretest

Based on the table above, it can be seen that the negative ranks are 4, meaning that four subjects experienced a decrease in value (score) from pretest to posttest. On the other hand, the positive ranks are 7 , meaning that there are seven subjects whose posttest scores increased from the pretest scores, while the ties are 0 , meaning that there are no subjects whose pretest and posttest scores are the same.

Based on the table above, it is noticed that the $p$-value is $0.75>0.05$, and the $\mathrm{Z}$ value is-1.778b. Thus, the finding states that there is no significant difference between the pretest and posttest results, so it can also be concluded that there is no effect between an Islamic-based innovation detox mind and CBRT techniques on the level of depression in students who are active in organizations.

Table 3: Ranks PWB

\begin{tabular}{|c|c|c|c|c|}
\hline & & $\mathrm{N}$ & Mean Ranks & Sum of Ranks \\
\hline Post Test - & Negative Ranks & $1^{\mathrm{a}}$ & 2.50 & 2.50 \\
Pre Test & Positive Ranks & $10^{\mathrm{b}}$ & & \\
& Ties & $0^{\circ}$ & 6.35 & 63.50 \\
& Total & 11 & & \\
\hline
\end{tabular}

a. Posttest $<$ Pretest

b. Posttest $>$ Pretest

c. Posttest $=$ Pretest

Based on the table above, it is noted that the negative rank is 1 , meaning that there is one subject who experienced a decrease in value from pretest to posttest. On the contrary, the positive ranks are 10 , meaning that there are ten subjects whose posttest values increased from the pretest values, 
while the ties are 0 , which means that there are no subjects whose pretest and posttest values are the same.

Based on the table above, it is found that the value of $p$ is $0.007<0.05$, and the value of $\mathrm{Z}$ is- $2.714^{\mathrm{a}}$. The finding states that there is a significant difference between the pretest and posttest results, so it can be concluded that there is an influence between the Islamic-based innovation detox mind and CBRT techniques on the psychological well-being of students who are active in organizations.

Table 4 shows the results of interviews and participant evaluations in each session.

Table 4: The results of interviews

\begin{tabular}{|c|}
\hline Irrational Believe Interview \\
\hline $\begin{array}{l}\text { For the balance between organization and academics, the subject } \\
\text { was more inclined to the academic. According to the subject, the } \\
\text { organization was an addition to enhance the subject's soft skills, } \\
\text { while academics was an obligation. The feeling that often arose } \\
\text { in the subject was nervous/restless. }\end{array}$ \\
\hline
\end{tabular}

For balance between organization and academic, the subject was more inclined to the academic with the level of 7 . The subject preferred more on academics because the subject felt that in the organizations, the subject only met the same people most of the time, and the subject did not like the organizational culture. The feelings that arose when the subject was in the organization's scope were boredom, discomfort, and even strange.

For the balance between organization and academics, the subject was more inclined or prioritizing the academic. According to the subject, joiningan organization was less valuable, boring, and caused much pressure. Feelings that arose when joining the organization were hate, upset, and anger.

For the balance between organization and academics, the subject was more inclined or prioritizing the academic with the level of 7 . The subject preferred academics was because the subject felt that academics were the most important thing at this time. The subject did not like organization because, according to him/her, many seniors/ boards were too regulated. While the feelings or emotions arose when there were academic activities, the subject felt enjoyed but was stressed out when the subject had many tasks/assignments.

For the balance between organization and academics, the subject was more inclined or prioritizing the academic. According to the subject, academics are the primary and mandatory thing, so if there were activities, the subject would always prioritize the academic first, whether the assignment or class meeting. However, apart from the academic activities, the subject filled his/her time by doing activities in the organization. Because, according to the subject, he/she always remembered the primary goal of joining an organization, to get benefits for him/herself, for community service, and to gain knowledge not acquired in academic activity.

For the balance between organization and academics, the subject was more inclined or prioritizing the organization. It was because the subject has been too focused on academics and lacks experience in organizations since childhood; therefore, the subject was more inclined to the organization during the study. The feelings that arose when joining the organization were enjoying, liking to have lots of friends, even though sometimes feeling tired because the activities were happening at the same time with academics.

For the balance between organization and academics, the subject was more inclined or prioritizing the organization. It was because, in the organization, the subject felt more fun to socialize and met many friends, and often the topics in the organization were more interesting and easier to understand.

The subject felt that academics and organization were equally important. There were times when the subject leaned towards academics but could also lean towards the organization, depending on the conditions. The thing that made the subject feel tired

\section{Evaluation}

After participating in sessions 1 to 5 of the detox mind, the subject felt calmer and more relaxed. Before following the mind detox, the subject got nervous easily about everything. However, after following the detox mind, the subject was calmer, more laid back and relaxed when conducting organizational discussions, more open with his/her family, and could manage his/her time well, and could schedule activities the subject wanted to do.

After participating in sessions 1 to 5 of the detox mind, the subject had not felt any significant changes, but there were new insights. For example, after following the detox mind, the subject was more open and felt that the subject should try to balance his/her college, personal, and organizational life. In addition, the subject believed that he/she could find solutions through religious ways.

After participating in sessions 1 to 5 of the detox mind, the subject had not felt any significant changes. However, the subject knew better what to do when facing complexities and believed that all problems could be overcome. In addition, the feeling felt by the subject was feeling calmer in dealing with something.

After participating in sessions 1 to 5 of the detox mind, the subject felt more enlightened about what they were doing and socializing. The subjectwas more able to control the conflict of the heart and mind. For example, when the heart wanted to rest and did not want to do many activities as long as the subject could do it consistently, the mind wanted to do many activities. So, the subject should think again, see what would happen when making a decision and be responsible for all possibilities. In balancing the organization and academics, the subject always tried to manage the time, set a target about what to do, respect each other more, and carry out all responsibilities.

After participating in the detox mind, the subject wanted to interpret the Qur'an verses more to live a peaceful life. In addition, the subject could understand and could accept what was obtained in life, did not always blame fate or him/herself when something bad happened, learned not to overthink about the future since there was no certainty in life and was rather started to do something useful which could bring impact for the future. The feelings experienced by the subject were feeling more relaxed and feeling more positive, and being more able to think that whatever happened in life had been ordained by God, so when someone failed in their maximum efforts, it means it was not their time yet to get it.

The subject did not feel anything significant, but felt more grateful for life, became calmer in dealing with things, and enjoyed every process of activities carried out.

The subject reported to have additional insights, and was able to learn that between organization and academic, as long as they could be done at the same time, then they could go hand in hand, but if not, then it would be a choice of which one was more of a priority or more needed at that time.

The subject felt that there was no significant feeling after participating in the detox mind. However, it was important for the subject to learn more about dealing with pressures and focusing on what came first but did not rule out one of them. 


\begin{tabular}{|c|c|}
\hline Irrational Believe Interview & Evaluation \\
\hline $\begin{array}{l}\text { quickly was when academics had many tasks and organization had } \\
\text { many activities, so the time was insufficient. }\end{array}$ & \\
\hline $\begin{array}{l}\text { For the balance between organization and academics, the subject } \\
\text { was more inclined or prioritizing the organization. According to } \\
\text { the subject, lectures were boring because the subject met the same } \\
\text { people most of the time, and he/she felt annoyed, angry, and did } \\
\text { not like the culture of creating exclusive groups/gangs in the class. }\end{array}$ & $\begin{array}{l}\text { The feelings arose after participating in the detox mind; the subject } \\
\text { felt happy, helped, and there was a spirit of improving time } \\
\text { management quality. In addition, the subject also had a new picture } \\
\text { of youth busyness which was full of organizational activities and } \\
\text { felt motivated to be able to balance the activities. Besides, the } \\
\text { subject also felt changes in his personality such as improving coping } \\
\text { stress, improving the quality of prayer and sunnah worship, trying } \\
\text { to be the best version every day by not forgetting muhasabah every } \\
\text { day. }\end{array}$ \\
\hline $\begin{array}{l}\text { For the balance between organization and academics, the subject } \\
\text { was more inclined or prioritizing the academic. So it was because, } \\
\text { according to the subject, academics was the main priority, while } \\
\text { joining the organization was a supporting activity. }\end{array}$ & $\begin{array}{l}\text { After participating in the detox mind, the subject felt more relaxed. } \\
\text { The subject knew the most comfortable way to relax. Previously, } \\
\text { the subject had never known that relaxing himself/herself was as } \\
\text { simple as that. The subject also felt that his/her personal and } \\
\text { organizational life was getting more balanced, although not entirely } \\
\text { because it was an adaptation period. }\end{array}$ \\
\hline $\begin{array}{l}\text { The subject felt that organization and academics are equally } \\
\text { important; academic to increase knowledge, while organization to } \\
\text { hone soft skills. }\end{array}$ & $\begin{array}{l}\text { The changes experienced by the subject after participating in the } \\
\text { detox mind were that he/she felt that the activities in the detox mind } \\
\text { intervention were beneficial for individuals who joined } \\
\text { organizations and could also add relationships. }\end{array}$ \\
\hline
\end{tabular}

\section{Discussion}

Students have various demands relating to tasks and activities in lectures and organizations. Therefore, it is not surprising if many students often experience stress or depression in completing these tasks. Through this study, to reduce the level of depression and to increase the level of psychological well-being in students who are active in organizations, the Islamic-based detox mind technique is used by using cognitive behavior religious therapy, which is a combined technique of spirituality and psychology by combining behavior and cognitive that accommodates Islamic values.

Based on the intervention process carried out by the researchers, it was found that each subject had a different view of the importance of academics and organizations.

Based on the calculation of depression using the Signed Ranks Wilcoxon, it was found that the $p$-value is $0.075>$ 0.05 , and the $\mathrm{Z}$ value is $-1.778 \mathrm{~b}$. Thus it can be concluded that there is no significant difference between the pretest and posttest in students who are active in organizations in East Java. Therefore, it can be inferred that the Islamic-based detox mind using cognitive behavior religious therapy technique are not effective in reduce the level of depression in students who are active in organizations, but detox Islamic-based mind based on effective cognitive behavioral religious therapy techniques to increase the level of psychological well-being in active students organize in East Java.

\section{Conclusion}

The current study results conclude that the Islamic-based detox mind based on cognitive behavior religious therapy techniques are not effective in reducing depression levels in students who are active in organizations. However, the Islamic-based detox mind based on cognitive behavior religious therapy techniques effectively increases the level of psychological well-being in students who are active in organizations in East Java.
The study's shortcoming is a decrease in the number of study subjects, where at the end of the study, the number of study subjects was reduced compared to the beginning of the study. It happened because several subjects could not be contacted, some were busy, and some were not willing to participate until the completion of the research.

Suggestions for further research are to pay more attention to the subjects, to always build good communication with the subjects, to apply an appropriate approach to know the condition of the subjects when doing the posttest and pretest, and to ensure the subjects do the assignment and follow the intervention as well as possible so that the subjects can do the tasks according to their actual conditions.

\section{References}

[1] Ahmad, S. (2017). Pengaruh Keaktifan Mahasiswa Dalam Mengikuti Organisasi Himpunan Mahasiswa Pendidikan Administrasi Perkantoran (HIMA ADP) Dan Disiplin Belajar Terhadap Prestasi Belajar Mahasiswa Program studi Administrasi Perkantoran Fakultas Ekonomi UNY. Jurnal Psikologi, 1 (1), 173200.

[2] Aries, D. (2016). Depresi: Ciri, Penyebab, Dan Penanganannya. Jurnal An-nafs, 1 (1), 20-30.

[3] Baiqahi, A. (2020). Seorang Mahasiswa Ditemukan Tewas Gantung Diri Di Surabaya. Surabaya: Detik news. Retrieved from https: //news. detik. com/beritajawa-timur/d-5084631/seorang-mahasiswa-ditemukantewas-gantung-diri-di-surabaya

[4] Eva, N., Shanti, P., Hidayah, N., \& Bisri, M. (2020). Pengaruh Dukungan Sosial terhadap Kesejahteraan Psikologis Mahasiswa dengan Religiusitas sebagai Moderator. Jurnal Kajian Bimbingan dan Konseling, 5 (3), 122-131.

[5] Fitriani, A. (2017). Cognitive Behavior Religious Therapy Untuk Menurunkan Tingkat Episode Depresi Pada Pasien Depresi Dengan Gejala Psikotik. Jurnal Psikologi Proyeksi, 12 (1), 77 - 87, http: //dx. doi. org/10.30659/jp.12.1.77-87. 
[6] Priskilla, N. M., Pamungkas, N. A. M, \& Pramesta, D. K. (2020). Hubungan Kecerdasan Emosional dan Stres Akademik pada Mahasiswa yang Mengikuti Organisasi dan School from Home. Prosiding Seminar Nasional LP3M, 2, 16, http: //proceeding. semnaslp3m. unesa. ac. id/index. php/Artikel/article/view/85

[7] Santrock, J. W. (2012). Life-Span Development: Perkembangan Masa-Hidup Jilid II (Edisi Ke-13). Jakarta: Erlangga.

[8] Tia Ramadhani, d. (2016). Kesejahteraan Psikologis (Psychological Well Being) Siswa Yang Orang Tuanya Bercerai. Jurnal Bimbingan Konseling, 5 (1), 1-11.

[9] Widhigdo, J. C., Ahuluheluw, J. M., \& Pandjaitan, L. N. (2020). Pelatihan ketangguhan untuk meningkatkan kesejahteraan psikologis pengurus unit kegiatan mahasiswa (UKM) di Universitas Surabaya. Jurnal Psikologi Ulayat: Indonesian Journal of Indigenous Psychology, 7 (2), 122-139. I 